\title{
Тесленко В.А.
}

Харківський національний університет будівництва та архітектури,

(Сумська, 40, Харків, 61002, Україна, е-mail: vlates@ukr.net; orcid.org/0000-0003-2743-7272)

\section{ВИКОРИСТАННЯ ПЕРЕРОБЛЕНИХ БУДІВЕЛЬНИХ МАТЕРІАЛІВ ПРИ ПРОЕКТУВАННІ АРХІТЕКТУРНИХ БУДІВЕЛЬ І СПОРУД. (ЕКОЛОГІЧНИЙ АСПЕКТ)}

На даний момент головною темою обговорень розвитку екологічного будівництва $є$ те, що у будівельних компаній з'являється багато альтернативних можливостей збільшити кількість відходів, які вони зможуть використовувати повторно або переробити. Були розроблені унікальні будівельні системи, що являються екологічно безпечними та енергоефективними.

Ключові слова: вторсировина; будівництво; середа; переробка; галузь.

Постановка проблеми. Світова будівельна індустрія використовує багато різних типів матеріалів у великих кількостях. На даний момент головною темою обговорень екологічної ситуації на планеті $\epsilon$ те, що у будівельних компаній з'являється багато альтернативних можливостей збільшити кількість відходів, які вони зможуть використовувати повторно або переробити.

На перший план виходять багато переваг, пов'язаних з утилізацією відходів, що залишилися після будівельних проектів. Переробка матеріалів знижує витрати на утилізацію і викиди вуглецю. Це також допомагає дотримуватися екологічного законодавства, економити і зменшувати кількість того, що може бути відправлено на смітник.

Часто сировина, що використовується на будівельних майданчиках, являє собою незаймані матеріали або об'єкти, які вже містять деяку кількість перероблених речовин. Проте, існують прості, але ефективні зміни, які можна додати в свої операції, щоб переробляти більше відходів.

Тема наукової статті «Використання перероблених будівельних матеріалів при проектуванні архітектурних будівель i споруд. (Екологічний аспект)» обумовлена не тільки актуальністю проблеми забруднення навколишнього середовища, 3 якою стикається світ, але й відсутністю відповідних правил і необхідних систем, експертів в цій області і незнання належного поводження 3 небезпечними і спеціальними відходами.
Екологічне або «зелене» проектування - це концепція більш ефективного використання сили при створенні менш ресурсномістких будинків, офісів, шкіл та інших будівель. Зростаюча популярність проектування i будівництва екологічно чистих будівель привела до появи безлічі підходів, які спрямовані на те, щоб орієнтувати архітекторів, дизайнерів, конструкторів і проектувальників на будівництво, що не завдає шкоди планеті [6].

Велика частина матеріалів, викинутих під час зведення будівлі або споруди, може бути фактично використана десь ще. У типовому житловому будинку, майже 75\% відходів можуть бути перероблені. Це означає, що велика частина будівельного сміття не вимагає вивозу на звалище.

Ось ділення відходів за типами $\mathrm{C} \&$ $\mathrm{D}$, які залишаються від житлової забудови або реконструкції, 75\% яких можна переробити:

$3 \%$ - метали;

$5 \%$ - камінь;

$8 \%$ - гіпсокартон;

9\% - архітектурні елементи або конструкції;

$20 \%$ - картон;

$30 \%$ - деревина;

Тільки близько 25\% від цієї сировини являються матеріали, які не можуть бути ефективно використані повторно або перероблені. У підсумку, виходить, що будівельні фірми можуть прибрати до 75\% твердих відходів зі звалищ [7].

Багато будівельних проектів складаються із важких процесів та робот, тому може бути важко визначити, скільки 
відходів створюється, і як зменшити їх відсоток або повторно використати їх. Проте, відходи можуть бути основним фактором витрат в процесі будівництва. Щоб звести до мінімуму кількість відходів у проекті, варто обміркувати роботу 3 ланцюжком поставок і подумати про те, як саме матеріали і відходи використовуються на протязі всього життєвого циклу проекту.

Деконструкція відноситься до ретельного демонтажу частин споруди або будівлі, щоб врятувати цінні будівельні матеріали. Зазвичай елементи, що демонтуються включають в себе двері, вікна, підлоги, стельову плитку, стільниці, освітлювальні та сантехнічні вироби, молдинги, покрівлю тощо.

Деконструкція має багато екологічних переваг, враховуючи, що будівельне сміття становить близько третини твердих відходів в світі. Зберігання більшої частини цих багаторазових будівельних відходів на звалищах робить значний вплив на навколишне середовище [5].

Переробка та повторне використання будівельних матеріалів зменшує потребу в сировині для нових проектів. Крім того, що деконструкція корисна для навколишнього середовища, вона також сприяє економії грошових ресурсів [10].

Купляючи більше перероблених i повторно використаних матеріалів в будівництві, можна скоротити загальні витрати. Існує два джерела потенційної економії коштів - повторне використання матеріалів для будівництва, а також впровадження відновлених і перероблених матеріалів.

Найбільш поширені області застосування перероблених продуктів:

- повторне використання матеріалів для земляних робіт - наприклад, шляхом стабілізації грунтів за допомогою гідравлічних зв'язуючих або отримання якісних грунтів шляхом додавання «зеленого» компосту;

- обробка будівельного майданчика, що виникає після знесення споруд прямо на місці - наприклад, використання мобільної дробильної установки для забезпечення перероблених наповнювачів для засипки і підстилаючих шарів (рис. 1);

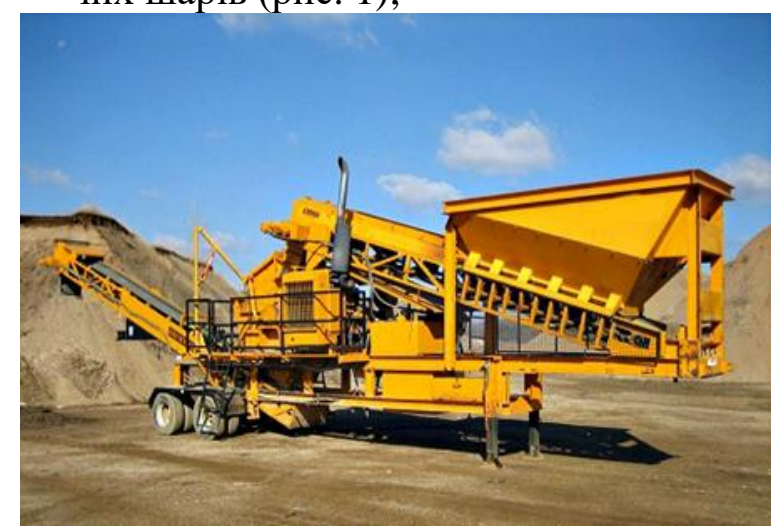

Рис. 1. Мобільна дробильна установка

- імпорт перероблених матеріалів, які відповідають тим же стандартам якості, що і первинні наповнювачі, які вони замінюють;

- поліпшення інженерних властивостей матеріалів - наприклад, за допомогою сполучних композитів для реабілітації існуючих конструкцій;

- використання продуктів з високим вмістом вторинної сировини, таких як асфальт або заміна цементу в бетонних виробах [10].

Але $є$ деякі перешкоди, щодо використання переробленої, вторинної сировини в невеликих або навіть малих проектах. Простір, час і пристрій можуть бути обмеженнями можливостей повторного використання матеріалів в невеликих проектах. Проте, все ще існують можливості для включення в будівництво матеріалів 3 інших майданчиків, які можуть бути доступні тільки в обмежених кількостях i, отже, краще підходять для невеликих проектів (рис. 2).

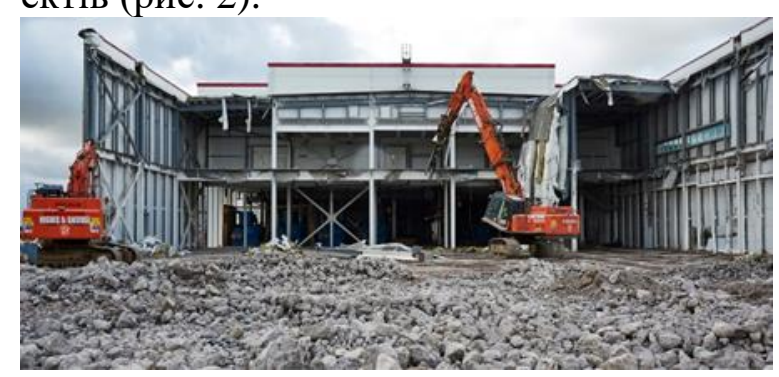

Рис. 2. Деконструкиія

Зараз вже $є$ повністю сформовані екологічні принципи архітектурного проектування: ріали; 
2. Альтернативні енергозберігаючі джерела енергії (до них відносять теплові насоси, сонячні колектори, а також котли енергетично вигідного і якісного спалювання сировини);

3. Правильні способи утилізації відходів;

4. Комфортна і здорова для людини система опалення (охолодження) за допомогою випромінюючих поверхонь, що передають тепло людині безпосередньо за допомогою хвиль, заздалегідь не підігріваючи повітря;

5. Економія енергії завдяки «теплим» стін, тобто стін, які правильно і добре утеплені;

6. Створення припливно-витяжної вентиляції, що забезпечує постійний приплив чистого повітря без ефекту протягу;

7. Раціональне проектування, компактність форм, правильність розташування світла і теплопропускних поверхонь [1].

Існує кілька рішень, як уникнути помилок під час екологічного будівництва або переробки матеріалів. Передбачені письмові стандарти, встановлені кодекси, сертифікаційні системи і задані інструменти.

- Часто розроблені професіоналами, інженерами і вченими комплексні стандарти екологічного будівництва, як правило, розбивають вимоги на окремі частини, такі як енергоефективність, якість повітря в приміщеннях, вивчення вибору ділянки та використання ресурсів. Вони часто встановлюють мінімальні критерії продуктивності і приділяють велику увагу докладним специфікаціям.

- Екологічні будівельні норми встановлені законом як обов'язкові вимоги, прийняті державної або місцевої юрисдикцією. В даний час професійні кодекси переглядаються і оновлюються на постійній основі, на відкритому публічному форумі, на якому поправки пропонуються, обговорюються, узгоджуються з фахівцями.

- Системи сертифікації екологічно чистих будівель включають вимоги, що містять список потенційних «кредитів» для досягнення рівнів продуктивності у відповідних категоріях.
- Інструменти «зеленого» будівництва дозволяють аналізувати конкретні аспекти проектування, такі як планування енергоефективності, аналіз якості повітря в приміщеннях або оцінку матеріалів. Ці інструменти можуть бути стандартами самі по собі, або іноді згадуються в цілих стандартах екологічного будівництва, кодексах і системах сертифікації [4].

Аналіз останніх досліджень і проектів. Будівництво будинків 3 нульовим викидом вуглецю і модернізація існуючих будівель пропонують деякі 3 найбільш економічно ефективних і найбільш швидких стратегій у відповідь на зміну клімату.

На сьогоднішній день вже запущене виробництво нових екологічних будівель, які будуються за суворими екологічними нормами, з пасивним сонячним дизайном, високою ізоляцією і екологічно чистими матеріалами.

У 2008 році на півночі Шотландії був відкритий центр образотворчих мистецтв Moray Art Center, що дає регіону виставковий простір високої якості і кілька студій. 3 панелями, що живлять електрику, і наземними тепловими насосами, що забезпечують все опалення, центр мистецтв вважається зразком використання вторинних матеріалів. Спроектований за допомогою прикладів, в яких представлено низький вплив на навколишнє середовище, завдяки екологічним матеріалами. 3 самого початку метою будівлі було мінімізувати поточні експлуатаційні витрати за рахунок інвестицій в ефективні системи опалення, освітлення, вентиляції та водопостачання. У проекті використовувалися матеріали місцевого виробництва i, по можливості, екологічно чисті будівельні матеріали. Центр мистецтв також користується екологічно чистої станцією очищення стічних вод «Жива Машина», яка знаходиться в еко-селі Фіндхорн. Будівля стало ресурсом для навчання, так як воно є моделлю екологічності та визнана в ряді архітектурних конкурсів (рис. 3,4 ) [9]. 


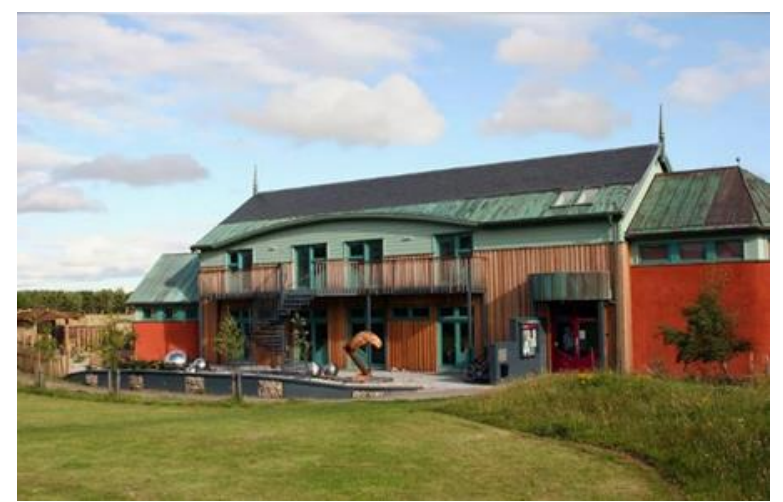

Puc. 3. Moray Art Center

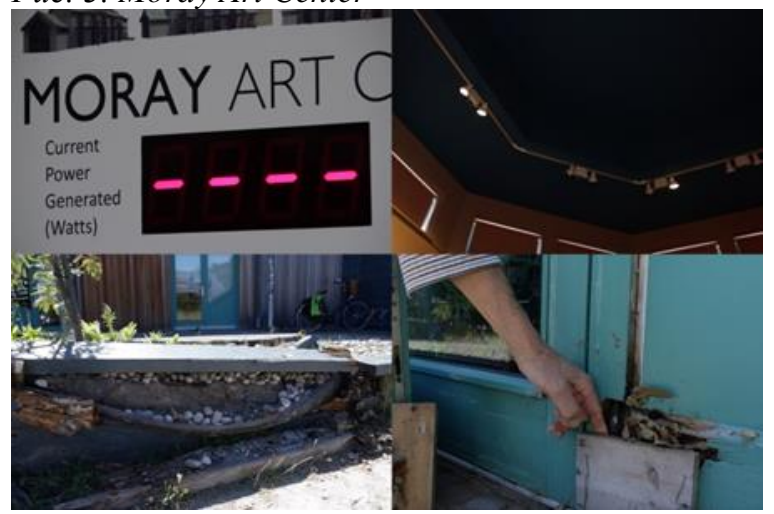

Puc. 4. Moray Art Center

У 2012 році був зведений житловий квартал «») - це інноваційне еко-поселення з 25 будинків - поєднання квартир і будинків - 3 вигодами для проживання, включаючи загальну кімнату, кухню та майстерні. Загальний дизайн заснований на соціальному просторі, де жителі отримують вигоду від спільної діяльності, включаючи приготування їжі, здоров'я, декоративно-прикладне мистецтво (рис. 5, 6).

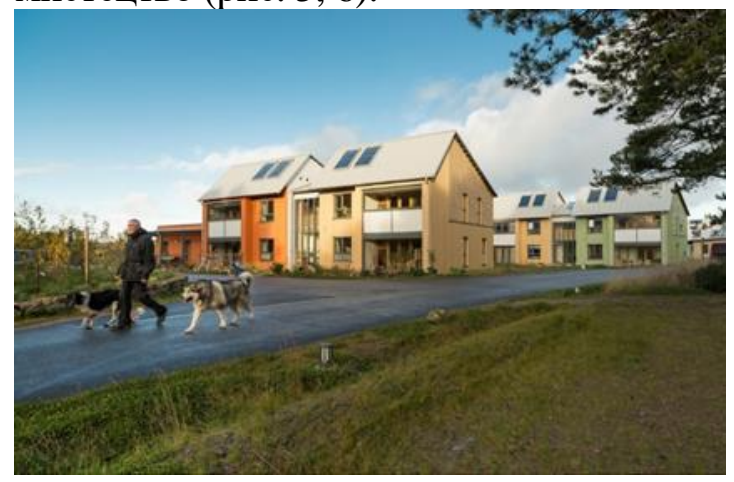

Рис. 5. Іст-Уінсом

Створене з використанням деревини і теплоізоляції з перероблених газет, екопоселення відповідає шотландським срібним стандартам енергоефективності.

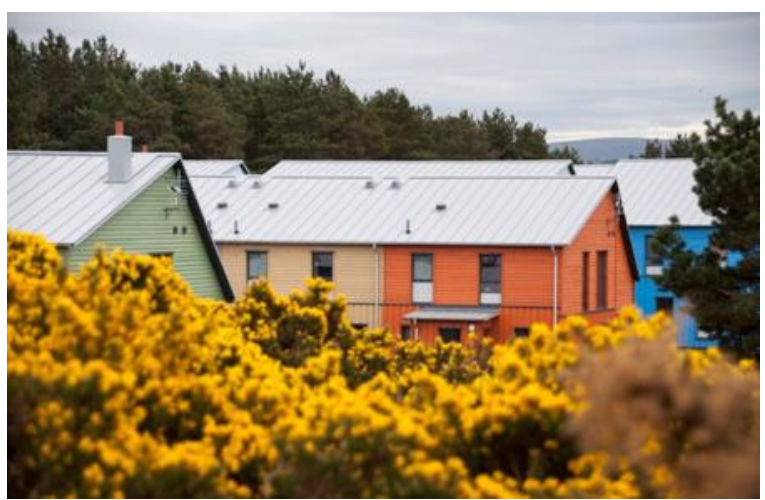

Рис. 6. Іст-Уінсом

Проект являє собою:

- Натуральні матеріали;

- Шотландська деревина;

- Пасивний сонячний дизайн;

- Зазначений нагородами проект;

- Широке участь спільноти. [8]

Далі представленні приклади переробки та повторного використання різних матеріалів у будівництві за європейськими стандартами:

- Переробка цегли. Цегла має термін служби більше 200 років. Є можливість відновити або переробити цеглини, які раніше використовувалися при будівництві будівель, стін, мощень та інфраструктур, таких як мости і каналізації. Вони включають: глиняні, бетонні цеглини, газоблоки, кам'яні блоки. Варіанти повторного використання цегли: зробити матеріал для додавання в якості основного заповнювача або дорожньої бази; в ландшафтному дизайні; зробити спортивні покриття, такі як тенісні корти і спортивні доріжки. Однак існують деякі обмеження на використання перероблених цегли і блоків, в тому числі: цеглини можуть бути забруднені іншими будівельними відходами, такими як гіпсокартон; очищення цегли займає багато часу i не завжди можливе; важко оцінити несучу здатність переробленої цегли. Рекомендується використання розчину на основі вапна, а не цементного розчину - це дозволить використовувати повторно цеглу після демонтування [3].

- Переробка скла. Велика частина відходів скла утворюється в результаті проектів по знесенню і заміні вікон в проектах 3 реконструкції. В матеріали для переробки також включають: флуоресцентне освітлення; ПК монітори та екрани 
телевізорів; структурне скло - наприклад, в сучасних офісних блоках. Можна утилізувати скло різними способами: дроблення; скринінг для видалення забруднень; прання та сушіння. Відновлене скло можна використовувати для: декоративних матеріалів; флюсу у виробництві цегли і кераміки; ізоляції. Проте, існують деякі обмеження на використання переробленого скла. Наприклад: витяг і відновлення скла може бути дорогим; завантаження і транспортування скла в центри збору склобою може бути дорогим і трудомістким [3].

- Переробка деревини. Відходи деревини можуть бути різних форм: піддони; ящики; балки; віконні та дверні коробки; двері; огорожі; панелі, такі як ДСП. Категорії деревини, які можуть бути перероблені: придатні для вторинної переробки і утилізовані матеріали - від будівництва, включаючи піддони, деревина подрібнюється для інших цілей; невідновлювані і не підлягають переробці відходи - наприклад, старі огорожі, ламіновані покриття підлоги та гнилі вікна і двері. Проте, існують деякі обмеження по переробці деревини, в тому числі: невідомі рівні забруднення; низька прибутковість; обмежений ринок - немає реальних ринків для вторинної ламінованої дерев'яної підлоги, оскільки вона часто містить клеї, пластмаси, змішані породи деревини і обробки поверхні; практичні труднощі при переробці деревини - наприклад, через кількість клею важко переробляти відходи деревостружкової плити. Відновлена деревина може використовуватися: ДСП, виробництво деревоволокнистих плит; постіль для тварин; ігрові поверхні і доріжки; архітектурні компоненти; ландшафтний дизайн [3].

- Утилізація гіпсокартону і гіпсу. Відходи: штукатурна плита; штукатурка. Втрати гіпсокартону від 10 до 35 відсотків можуть бути отримані на місці під час установки. Основними причинами є: обрізки; поганий дизайн; погане зберігання і обробка. Варіанти утилізації відходів гіпсокартону, вироблених на будівельному майданчику, включають в себе: повернення відрізів виробнику для переробки за схемами повернення; відправка відходів незалежним переробникам гіпсокартону для виробництва нових елементів. Проте, існують деякі обмеження по переробці гіпсокартону, в тому числі: старий гіпсокартон, знятий в проектах по знесенню і ремонту, може бути забруднений іншими матеріалами. Можна використовувати відновлений гіпсокартон в ряді будівельних елементів і матеріалів, включаючи: суху підкладкову дошку для стін, стель i підлог; будівництво дорожнього фундаменту; молдинги меблів для ванної кімнати [3].

- Переробка ізоляції. Велика частина відходів ізоляції надходить 3 проектів по знесенню та реконструкції. Ізоляційні матеріали включають в себе: скляну і кам'яну вату; полістирол; аерозольну піну; поліуретан; фіброліт. Варіанти утилізації відходів ізоляції включають в себе: виробництво стельової плитки з пресованої кам'яної вати; відновлення та переробку після видалення забруднень, таких як гвинти і цвяхи. Можна використовувати ізоляційні відходи в ряді будівельних матеріалів, в проектах реконструкції - наприклад, ізоляція зі скловолокна і кам'яної вати може бути включена в бетонні блоки або скловолокно; склопластикову стельову плитку [3].

Формування мети статті. Актуальність роботи полягає в спрямованості сучасної архітектури на детальне вивчення особливостей експлуатація вторсировини, а екологічно безпечні архітектура і дизайн виходять на передній план цієї «зеленої революції». У той час як багато проектувальників спираються на практику минулих років, повторне використання перероблених матеріалів починають виділяти як інноваційне, високоефективне і художнє вираження екологічного дизайну [2]. За останні роки були розроблені унікальні будівельні системи, екологічно безпечні та енергоефективні.

Висновки. У висновку, велика частина будівельних відходів потрапляє на звалища, що збільшує навантаження на експлуатацію місць зберігання сміття. Деякі матеріали можуть бути перероблені для повторного використання. Багато 
будівельних матеріалів, які все ще придатні для використання, можуть бути передані некомерційним організаціям. Найбільш важливим кроком для утилізації будівельних відходів $є$ сортування на місці. Спочатку для цього будуть потрібні додаткові зусилля і навчання будівельного персоналу. Першим елементом в стратегії скорочення будівельних відходів $є$ гарне планування. Дизайн повинен грунтуватися на стандартних розмірах, а матеріали повинні бути замовлені в точній кількості. Крім того, використання високоякісних матеріалів, таких як інженерні продукти, зменшує кількість браку. Такий підхід може зменшити кількість матеріалу, що підлягає переробці, і підвищити рентабельність і економію для будівельника і клієнта.

Будівельні відходи утворюються в результаті зведення споруд або робіт по знесенню будівель, що складаються з бетону, черепиці, цегли, гіпсокартону, асфальту, пластмас, металів, дерева, каміння і багато чого іншого. Ці будівельні відходи часто $є$ інертними i не здатні біологічно руйнуватися, важкими, громіздкими і перевантажують полігони. Переробка та управління будівельними відходами включає в себе процес і поділ утилізації сміття для повторного використання.

Результати дослідження дають можливість розгляду центру реабілітації відходів не як «проблему для вирішення», а як «можливість розвиватись».

\section{ЛІТЕРАТУРА:}

1. Тесленко. В. А., Овчарова К. О. Безпечне сприйняття еко архітектури. Науковий вісник будівнищтва. 2016. №1(83). С. 9-13.

2. Тесленко В. А., Асланова О. Д. Новітні тенденції технологій переробки та використання вторинної сировини в будівництві. Науковий вісник будівництва. 2018. Т. 92. № 2. C. $118-124$.

3. Переробка будівельних матеріалів. Керівництво. 2015. 378c

4. ASHRAE стандарти. Стратегічний план. Затверджено StdC 2 липня 2014 р.

5. ASHRAE стандарт 189.1-2017

6. Building with chemistry: веб-сайт. URL: https://buildingwithchemistry.org/greenbuilding/

7. Junk-King: веб-сайт. URL: https://info.junkking.com/construction-debris-recycling-as-astrategy

8. John Gilbert Architect: веб-сайт. URL: http://www.johngilbert.co.uk/?portfolio_page $=\mathrm{d}$ uneland-ecovillage

9. Moray Art Centre: веб-сайт. URL: https://www.morayartcentre.org/architecture

10. Nibusinessinfo.co.uk: веб-сайт. URL: https://www.nibusinessinfo.co.uk/content/reuseand-recycle-construction-materials

ТесЛеНКО В.А. ИСПОЛЬЗОВАНИЕ ПЕРЕРАБОТАННЫХ СТРОИТЕЛЬНЫХ МАТЕРИАЛОВ ПРИ ПРОЕКТИРОВАНИИ АРХИТЕКТУРНЫХ ЗДАНИЙ И СООРУЖЕНИЙ. (ЭКОЛОГИЧЕСКИЙ АСПЕКТ) На данный момент главной темой обсуждений развития экологического строительства является то, что в бу-градостроитель- компаний появляется много альтерных возможностей увеличить количество отходов, которые они смогут использовать повторно или переработать. Были разработаны уникальные строительные системы, являются экологически безопасными и энергоэффективными.

Ключевые слова: вторсырье; строительство; среда; переработка; отрасль.

Teslenko V. A., Aslanova O.D. USAGE OF RECYCLED BUILDING MATERIALS IN CIVIL AND STRUCTURAL DESIGN. (ECOLOGICAL ASPECT) Currently the main subject of discussion of the growth of ecological construction is that building contractors have many alternative ways to increase amount of waste, which can be reused or recycled. There were elaborated unique building systems that are environmentally friendly and energy efficient.

Keywords: recycled materials; civil engineering; environment; recycling; industry. 